\title{
IKONITAS PEREMPUAN DALAM NOVEL GRAFIS EMBROIDERIES KARYA MARJANE SATRAPI
}

\author{
Herson Kadir dan Jein Palilati \\ Fakultas Bahasa dan Sastra Universitas Negeri Gorontalo \\ email: hersonung@gmail.com
}

\begin{abstract}
Abstrak
Penelitian ini bertujuan mendeskripsikan ikonitas perempuan dalam novel grafis Embroideries karya Marjane Satrapi dengan menggunakan teori semiotika Charles Sanders Peirce. Metode yang digunakan dalam penelitian ini adalah metode deskriptif kualitatif. Pengumpulan data menggunakan teknik studi pustaka. Analisis data dilakukan dengan cara: (1) mengidentifikasi tanda ikon; (2) mengklasifikasi satu per satu tanda ikon yang telah diidentifikasi berdasarkan teori semiotika Peirce; dan (3) menganalisis data yang mengandung ikon imagi, diagramatis, dan metaforis. Hasil penelitian menunjukkan bahwa cerita dalam novel grafis Embroideries secara imagi, diagramatis, dan metaforis menggambarkan ikonitas kehidupan perempuan yang mengalami inferioritas, baik posisinya sebagai gadis, istri, maupun sebagai janda.
\end{abstract}

Kata kunci: ikonitas perempuan, novel grafis, semiotik

\section{WOMEN'S ICONITY \\ IN MARJANE SATRAPI'S GRAPHIC NOVEL EMBROIDERIES}

\begin{abstract}
This study aims to describe the icons of women in Marjane Satrapi's graphic novel Embroideries by using Charles Sanders Peirce's semiotic theory. This was a qualitative descriptive study. The data were collected by the library research technique. The data were analyzed by: (1) identifying icon signs; (2) classifying icon signs that had been identified one by one based on Peirce's semiotic theory; and (3) analyzing data containing image, diagram, and metaphor icons. The results show that the story in the graphic novel Embroideries in terms of image, diagram, and metaphor icons describes the iconity of the life of women experiencing inferiority, either as a girl, a wife, or a widow.
\end{abstract}

Keywords: women's iconity, graphic novel, semiotic

\section{PENDAHULUAN}

Persoalan perempuan menjadi materi menarik yang sering dibahas dalam semua aspek, termasuk dalam karya sastra. Di dalam karya sastra persoalan perempuan telah banyak yang diartikulasikan oleh pengarang, misalnya saja dengan hadirnya beberapa novel Indonesia, seperti Siti Nurbaya karya Marah Rusli, Belenggu karya Armijn Pane, Layar Terkembang karya Sutan Takdir Alisjahbana, dan Namaku Hiroko karya N.H Dini. Novel-novel tersebut melukiskan persoalan perempuan dengan cara dan tema kehidupan yang berbedabeda. Demikian pula dengan novel berjudul Embroideries karya Marjane Satrapi. Di dalam novel ini, persoalan perempuan di-exposure oleh pengarang dengan cara yang berbeda pula, dikarenakan novel ini termasuk gendre fiksi grafis.

Novel grafis merupakan novel yang secara format tersusun atas kata-kata dan gambar. Senada dengan pendapat Frey dan Fisher (2008: 175) bahwa graphic novel 
is a picture book combine words and pictures to tell a story, berarti novel grafis merupakan kombinasi antara teks dan gambar untuk menyampaikan isi ceritanya. Berdasarkan pendapat tersebut dapat dipahami bahwa novel grafs mengandalkan kemampuan teks dan gambar sebagai kekuatan utama dalam menyampaikan isi ceritanya. Hal demikian dapat dilihat dalam novel grafis Embroideries karya Marjane Satrapi. Novel grafis ini menceritakan tentang kehidupan para perempuan dengan latar sosial kehidupan negara Iran. Kisah kehidupan para perempuan Iran ini disampaikan dalam bentuk teks dan gambar. Oleh sebab itu, makna dari teks yang tertulis maupun yang tergambar di dalam novel grafis ini, dapat diungkapkan dengan menggunakan teori semiotika Charles Sanders Peirce.

Teori Peirce menjadi grand theory dalam semiotika. Prinsip dasarnya adalah bahwa tanda bersifat representatif yaitu tanda adalah sesuatu yang mewakili sesuatu yang lain (something that represent something else). Artinya tanda berfungsi untuk menunjukkan sesuatu, dan penerima tanda atau sang penafsirlah yang memaknai tanda tersebut berdasarkan pengalamannya masing-masing. Peirce memandang tanda sebagai struktur yang terdiri atas tiga dimensi. Titik sentral dari semiotika Peirce sebenarnya adalah sebuah trikotomi dasar mengenai hubungan tiga unsur tanda yaitu antara representamen (sign), objek, dan interpretan, atau sering disebut Triangle Meaning Peirce. Cara kerja tanda menurut Peirce, dapat dijelaskan melalui konsep Triangle Meaning (segitiga makna), sebagai berikut.

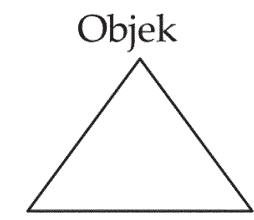

Representamen Interpretan

(Zaimar, 2013: 3)
Pembedaan tipe-tipe tanda yang paling simpel adalah ikon (icon), indeks (index), dan simbol (symbol) yang di dasarkan atas relasi antara tanda dengan acuannya. Tinarbuko (2013: 16-17) menjelaskan bahwa ikon adalah tanda yang mirip dengan objek yang diwakilinya. Indeks berarti tanda yang memiliki hubungan sebabakibat dengan apa yang diwakilinya atau disebut juga sebagai tanda bukti. Simbol merupakan jenis tanda yang konvensional (kesepakatan bersama). Simbol baru dapat dipahami jika seseorang sudah mengerti arti yang disepakati sebelumnya.

Ikon memiliki posisi yang cukup penting dibandingkan kedua tanda lainnya. Hal ini bukan berarti bahwa peran dari indeks dan simbol tidak cukup penting, namun perlu diketahui bahwa ikon yang tercipta atas hubungan "persamaan" dengan objek yang dituju menjadi dasar penting dalam proses terbentuknya indeks dan simbol. Hal tersebut sejalan dengan pendapat Zoest (dalam Noor, 2005: 87) bahwa dari ketiga tipe tanda itu, tanda ikonlah yang utama. Ini disebabkan semua yang diperlihatkan realitas kepada kita mempunyai kemungkinan untuk dianggap sebagai tanda, baik itu tanda konkret maupun abstrak.

Ikon tidak hanya dapat diidentifikasikan secara sempit pada kemiripan citrawi, melaikan juga pada kemiripan struktural atau diagramatis, bahkan pada kemiripan di antara dua objek simbolis sehingga terciptalah tanda metaforis. Senada dengan hal tersebut, Budiman (2011: 83-85) menjelaskan bahwa Peirce membagi ikon ke dalam tiga jenis, yaitu: (1) ikon imagi (image) adalah tanda-tanda yang tergolong ke dalam kualitas sederhana, yang secara alamiah mampu menampilkan kemiripan citrawi dengan objek yang diacunya, berupa gambar/foto; (2) ikon diagramatis adalah tanda-tanda yang menjelaskan hubungan diadik berdasarkan persamaan struktur, dengan kata lain ikon diagramatik mampu menampilkan 
suatu deskripsi relasional atau struktural. Contoh hubungan relasional adalah keadaan tokoh, dan contoh hubungan struktural adalah susunan hari; dan (3) ikon metaforis tanda-tanda yang menjelaskan karakter dari sebuah tanda berdasarkan pada kemiripan dua tanda simbolis. Ikon metafois dapat juga dipahami dengan deskripsi istilah yang memakai metafora antara dua objek acuan yang diwakili oleh sebuah tanda. Kemiripan tanda dengan objek yang mewakilinya menjadikan aspek ikon menjadi sesuatu yang sangat penting untuk didedah. Hal itu penting, karena menurut Muhith (2003:9) bahwa aktivitas berbahasa baik dengan gerak isyarat tubuh, reportoar dan ritual tindakan, pakaian yang dikenakan, dengan gambar-gambar grafis dan segala macam praktek kultural dapat disebut sebagai praktek-praktek penandaan. Di dalam novel grafis terdapat banyak praktek penandaaan seperti itu. Melalui praktek penandaan tersebut tentunya dapat diketahui dan diperoleh makna melalui telaah semiotik.

Sehubungan dengan hal itu, maka penelitian ini lebih difokuskan pada aspek ikonitas perempuan pada salah satu novel grafis yang berjudul Embroideries karya Marjane Satrapi.

\section{METODE}

Metode yang digunakan dalam penelitian ini adalah metode deskriptif kualitatif. Data dalam penelitian ini berupa kutipan teks dan gambar yang mengandung ikonitas perempuan dalam novel grafis Embroideries karya Marjane Satrapi. Adapun sumber data dalam penelitian ini yaitu novel grafis Embroideries karya Marjane Satrapi yang diterbitkan oleh PT. Gramedia Pustaka Utama pada tahun 2006. Format novel ini yaitu novel grafis bernuansa gelap (warna dominan hitam) dan berjumlah 136 halaman.

Teknik pengumpulan data yang digunakan dalam penelitian ini adalah teknik studi kepustakaan. Adapun langkah-langkah pengumpulan data dalam penelitian ini sebagai berikut: (1) membaca secara keseluruhan novel grafis Embroideries secara berulang-ulang untuk menemukan kehadiran tanda yang mengandung ikonitas perempuan; (2) membaca bagian-bagian cerita tertentu dalam novel grafis Embroideries yang menunjukkan adanya ikonitas perempuan; (3) mencatat/ menggaris bawahi bagian teks/gambar yang berhubungan dengan ikonitas perempuan yang terdapat dalam novel grafis Embroideries. Selanjutnya data-data tersebut dianalisis dengan berdasarkan langkah-langkah berikut: (1) mengidentifikasi tanda ikon yang terdapat dalam novel grafis Embroideries karya Marjane Satrapi; (2) mengklasifikasi satu per satu tanda ikon yang telah diidentifikasi berdasarkan teori semiotika Peirce; (3) menganalisis data yang mengandung ikon imagi, diagramatis, dan metaforis dalam novel grafis Embroideries berdasarkan teori semiotika Peirce; (4) mendeskripsikan data sesuai dengan permasalahan yang telah dianalisis; (5) melakukan verifikasi keseluruhan data yang mengandung ikon imagi, diagramatis, dan metaforis dalam novel grafis Embroideries karya Marjane Satrapi.

\section{HASIL PENELITIAN}

Ikonitas merupakan gejala dari tanda yang disebut dengan ikon (kemiripan). Ikonitas dalam penelitian ini dititikberatkan pada ikonitas perempuan yang terdapat dalam novel grafis Embroideries Karya Marjane Satrapi. Ikonitas tersebut ditinjau berdasarkan ikon imagi, ikon diagramatis, dan ikon metaforis. Hasil penelitian diuraikan sebagai berikut.

\section{Ikon Imagi Perempuan dalam Novel Grafis Embroideries karya Marjane Sa- trapi}

Ikonitas perempuan yang terbangun dalam percakapan antara tokoh Nahid 
dan tokoh nenek Satrapi ditandai oleh kata "perawan". Secara ikonik imagi, kata perawan menandai selaput dara yang sesungguhnya. Kata "perawan" adalah ikonitas dari seorang perempuan yang belum menikah dan dalam beberapa konteks kebudayaan dianggap sebagai perempuan yang masih murni/suci (selaput daranya belum koyak). Hal ini dapat dilihat dalam kutipan berikut.

"Aku tidak perawan lagi!"

"Apa? Apa maksudmu? Siapa yang melakukannya?"

"Gholii"

"Ooh, jadi itu namanya, pacar gelapmu itu? Kenapa dia berbuat begitu? Dasar bajingan!"

"Aku cinta dia, dia juga cinta aku.. aku mendatanginya untuk mengucapkan selamat tinggal... kami tidak bermaksud... Terjadi begitu saja..."

"Terjadi begitu saja!!!"

"Ya.. Aku akan menikah 19 hari lagi. Suamiku akan tahu aku tidak perawan lagi. Semua orang akan tahu! Ayahku bakal membunuhku! (Embroideries, 2006: 15)

Kutipan di atas menunjukan sebuah citra masyarakat Iran yang akan bertindak tegas terhadap seorang perempuan yang kehilangan keperawanannya sebelum menikah. Bahkan seorang ayah akan sanggup membunuh anak perempuannya jika diketahui bahwa anak tersebut sudah tidak perawan lagi. Jadi dapat dipahami bahwa dalam sebuah kultur masyarakat, khususnya di Iran tindakan tersebut dapat dikatakan sebagai pembunuhan demi kehormatan. Kutipan yang telah dipaparkan di atas merupakan bentuk ikonitas yang mengangkat derajat kaum perempuan, karena sebenarnya dengan mengatasnamakan budaya "malu" yang selama ini dijunjung oleh masyarakat Iran, tindakan tersebut merupakan sebuah bentuk penjagaan terhadap kehormatan perempuan.
Negara Iran yang digunakan sebagai latar penceritaan dalam novel grafis ini berpedoman pada nilai-nilai agama, karenanya keperawanan menjadi hal yang sangat penting bagi perempuan. Mereka percaya bahwa di situlah letak kesucian dan kesempurnaan iman seorang perempuan. Kehormatan perempuan juga dikait-kaitkan dengan keperawanan yang dimilikinya. Hal tersebut sesuai dengan ilustrasi berikut ini.

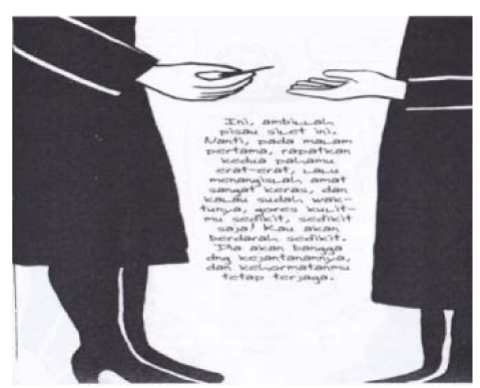

Gambar setengah tubuh perempuan Sumber: Novel Grafis Embroideries, 2006: 17

Secara ikonik imagi, perempuan yang digambarkan tidak secara utuh, hanya setengah dari bagian kaki hingga ke batas perut menandai keadaan tubuh perempuan yang sesungguhnya. Hal tersebut dapat dimaknai bahwa kehormatan seorang perempuan sejatinya terletak pada tubuh bagian bawahnya. Bagian bawah tubuh perempuan merupakan sesuatu yang harus dijaga, sesuatu yang suci karena di bagian bawah tersebut terdapat hymen (selaput dara).

Ilustrasi tersebut menjelaskan tentang konsep kehormatan perempuan dalam pandangan masyarakat Iran selalu diidentikan dengan hymen. Selain itu, ilustrasi tersebut sekaligus menjelaskan bahwa perempuan tidak pernah dilihat secara totalitas. Hal ini merupakan ikonitas yang merendahkan derajat kaum perempuan, sebab kedudukan perempuan dalam kultur Iran tidak dipandang dari segala aspek melainkan hanya dipandang sebatas pada tubuh bagian bawahnya saja. Kehadiran mereka dibutuhkan hanya setengah-se- 
tengah. Dengan kata lain, perempuan tidak begitu diperhitungkan kedudukannya dalam konteks sosial masyarakatnya.

Keperawanan perempuan begitu dipuja kehadirannya. Keperawanan seolah menjadi ukuran yang paling sakral untuk memberikan penilaian harga diri terhadap perempuan. Perempuan yang tidak memilikinya dianggap sebagai orang yang tidak punya harga diri, begitu pula dengan seorang janda cerai. Secara ikonik imagi, janda cerai merupakan tanda yang merujuk pada perempuan yang dinikahi oleh laki-laki lalu ditinggalkan. Seorang perempuan yang tidak mampu mempertahankan rumah tangganya dan berujung perceraian akan dianggap sebagai perempuan yang tidak punya harga diri, sebagaimana kutipan berikut.

\section{Kutipan 1}

"Kakakmu menikahi janda cerai. Perempuan brengsek yang tidak punya HARGA DIRI!! Apa kau sadar akibatnya bagi kita? Dan sekarang kau mau mengikuti jejaknya!!??" (Embroideries, 2006: 50)

Kutipan 2

"...Tapi tidak akan ada orang yang mau menikahi janda cerai" (Embroideries, 2006: 112)

Keadaan sosial masyarakat yang menganggap bahwa janda cerai adalah perempuan yang tidak punya harga diri merupakan ikonitas perempuan dalam kehidupan masyarakat Iran. Mereka menganggap bahwa perempuan yang diceraikan oleh suaminya hanya akan membawa pengaruh buruk bagi lingkungannya. Perempuan yang berstatus sebagai janda cerai dianggap sebagai orang yang tidak punya harga diri. Ada dua kecacatan yang dimiliki oleh perempuan yang berstatus sebagai janda cerai. Pertama, janda cerai adalah orang yang sudah tidak perawan, dan kedua janda cerai sejatinya dianggap sebagai seorang perempuan yang telah dipermainkan oleh laki-laki. Hal itulah yang memperburuk citra perempuan janda dalam kultur masyarakat Iran. Kutipan tersebut adalah bentuk ikonitas yang merendahkan perempuan, sebab jika dia perawan dia akan dipuja, sebaliknya jika perempuan tersebut adalah janda yang dicerai, dia justru akan dilabeli sebagai perempuan yang tidak punya harga diri.

Di dalam novel grafis ini juga diceritakan tentang keadaan tokoh Shideh, seorang perempuan janda yang menjalin hubungan dengan seorang laki-laki yang tidak berniat menikahinya. Adapun kekasih tokoh Shideh tersebut terlihat seperti seorang laki-laki yang tidak berani mengambil keputusan. Dia mencintai Shideh namun tidak berniat menikahinya. Hal ini dapat dilihat dalam kutipan berikut.

"Maka dia mengusulkan pada Shideh agar mereka tetap sama-sama seperti itu, tanpa menikah." (Embroideries, 2006: 51)

Kutipan di atas menunjukan ikonitas dari perempuan yang statusnya sudah menjanda dan tinggal bersama kekasihnya tanpa ikatan pernikahan. Hal ini merupakan sebuah perbuatan yang bertentangan dengan nilai moralitas perempuan Iran. Perbuatan tersebut berakar dari gaya hidup sekuler yang tumbuh di dunia Barat dan tidak pernah dibenarkan dalam pandangan ketimuran yang berlaku di Iran. Menurut Jamaluddin (2013: 309) sekularisme merupakan sebuah paham yang hanya mengedepankan pada kebendaan semata dan memisahkan antara kehidupan dunia dengan akhirat, bahkan faham ini selalu memperjuangkan hak untuk bebas dari berbagai aturan-aturan dari ajaran agama, mereka berkeyakinan bahwa semua kegiatan keputusan yang keseluruhannya berada dan dibuat oleh manusia, tidak boleh ada peran dan campur tangan agama di dalamnya. 
Hidup bersama tanpa ikatan pernikahan seperti dalam kutipan tersebut mengindikasikan sebuah perbuatan zina. Perbuatan ini tentunya ditentang oleh kultur Iran yang bersandar pada agama sebagai porosnya. Kutipan tersebut adalah bentuk ikonitas yang merendahkan kaum perempuan, sebab pada akhirnya hidup bersama seorang laki-laki tanpa ikatan pernikahan hanya akan merugikan pihak perempuan serta dapat memperburuk citra perempuan dalam lingkungan sosialnya.

Keperawanan perempuan adalah hal yang istimewa. Sebagaimana telah melekat kuat dalam pandangan masyarakat Iran bahwa keberadaan hymen juga diidentikan dengan moralitas perempuannya. Hymen juga menentukan apakah perempuan tersebut bermoral atau tidak. Akibat dari kultur yang menilai kehormatan, kesucian, harga diri, serta moralitas perempuan terletak pada hymennya, maka tekhnologi kedokteran di Iran menjadi lebih modern menyikapi masalah tersebut. Hal ini dibuktikan dengan hadirnya alternatif mengoperasi hymen bagi perempuan yang kehilangan keperawanannya. Perbuatan ini juga dianggap sebuah bentuk kemerosotan moral perempuan, sebagaimana dalam kutipan berikut.

"Sudah jelas! Moral kaum perempuan sudah lebih longgar! Zaman sekarang ini gadis-gadis sudah tidak perawan lagi sebelum menikah. Mereka bersikap sebebas laki-laki dan minta "dijahit" lagi sewaktu akan menikah!" (Embroideries, 2006: 81)

Secara ikonik imagi, kata "dijahit" menandai adanya sesuatu yang disambung atau dilekatkan kembali. Pada kutipan kalimat yang telah dipaparkan tersebut kata "dijahit" menandai dijahitnya selaput dara perempuan yang sudah tidak perawan. Cara inilah satu-satunya yang menjadi alternatif untuk tetap bisa perawan. Jadi saat menikah nanti semua pihak senang karena mendapati anak perempuan yang masih perawan. Padahal tindakan menjahit kembali selaput dara (hymenoplasty) mengandung unsur penipuan, karena hakikatnya perempuan tersebut sudah tidak perawan lagi namun ditutupi dengan cara "dijahit". Hal inilah yang selama ini terjadi pada perempuan-perempuan Iran yang sudah tidak perawan, lalu menutupinya dengan tindakan tersebut.

Penilaian moralitas seorang perempuan sering dikaitkan dengan keutuhan hymen. Seorang perempuan yang sudah tidak perawan sama artinya dengan perempuan tersebut sudah tidak memiliki moralitas lagi. Mereka telah melupakan konsep penilaian moralitas seorang perempuan yang selama ini sering dikaitkan dengan hymen yang dimilikinya. Kutipan tersebut tentu saja menjadi ikonitas perempuan Iran yang ternyata sudah mulai terjerumus ke dalam pergaulan bebas. Penilaian moralitas perempuan berdasarkan hymen yang dimilkinya sebagaimana kutipan tersebut sebenarnya merupakan usaha masyarakat untuk menyelamatkan anak perempuan dari pergaulan bebas. Ukuran moralitas berdasarkan hymen memang terlihat kolot di satu sisi, namun pada sisi lainnya hal ini merupakan bentuk penjagaan masyarakat Iran kepada perempuannya agar tidak menjadi korban modernisasi dan liberalisasi.

Mitos keperawanan sebagai ukuran kesucian dan moralitas seeorang perempuan telah membuat orang tua berusaha menjaga anak perempuannya dengan sebaik-baiknya. Usaha untuk tetap mempertahankan kehormatan keluarga, yang sering dikaitkan dengan kehormatan anak perempuan menjadikan orang tua di Iran mengambil keputusan untuk menjodohkan anaknya, tidak peduli laki-laki yang akan dijodohkan dengan anaknya tersebut berusia jauh lebih tua dari anaknya. Hal terpenting adalah mereka dapat mempertahankan kehormatan anak perempuannya, kehormatan keluarga, serta menghin- 
darkan anak perempuan mereka dari perbuatan-perbuatan yang bertentangan dengan norma sosial. Namun, seringkali tindakan perjodohan yang terjadi hanya merupakan sebuah alternatif untuk menikahkan anak perempuan mereka dengan orang yang sederajat. Hal ini dapat dilihat dalam kutipan berikut.

Kutipan 1

"Berhubung aku berasal dari keluarga aristokrat, sudah dipastikan aku bakal menikah dengan menteri atau pejabat. Jadi, aku sudah dijodohkan dengan seorang Jenderal Angkatan Darat yang umurnya lima puluh enam tahun lebih tua daripada aku."(Embroideries, 2006: 25)

\section{Kutipan 2}

"Jenderal Mafakherolmalouk datang untuk melamarmu. Pernikahan akan dilangsungkan sebulan lagi."

"Tidak! Aku tidak mau!"

"Aku tidak minta pendapatmu. Kau akan menikah!!! Titik! Itu sudah diputuskan!!" (Embroideries, 2006: 28)

\section{Kutipan 3}

"Bahar akan menikah! Kau dengar? Putriku akan menikah!!!"

"Tapi dia baru saja lulus SMA!"

"Laki-laki yang akan menikahinya itu multijutawan! Dia punya tujuh rumah di London, dua di Monaco."

"Multijutawan di London? Tapi berapa umurnya?"

"Empat puluh satu! Dia tinggal di Inggris selama 25 tahun belakangan ini. dia lulusan Royal College..." (Embroideries, 2006: 87)

Tindakan perjodohan dalam kutipan tersebut menjadi ikonitas perempuan Iran, khususnya mereka yang berasal dari kalangan aristokrat. Perjodohan terjadi karena masih banyaknya pemahaman di kalangan orang tua bahwa anak adalah "hak milik" bagi mereka (Sopariyanti, 2008: 4). Pada kasus perjodohan seperti dalam kutipan tersebut, anak perempuan seringkali digunakan sebagai alat untuk memperoleh kekuasaan. Mereka tidak diperbolehkan menikahi laki-laki pilihannya.

Tujuan menikahkan anak perempuan dengan orang yang sederajat sebagaimana dalam kutipan tersebut adalah agar para orang tua tetap memiliki kehormatan yang berlipat di mata masyarakat. Selain berhasil menjaga kehormatan anak gadisnya, mereka pun berhasil mempertahankan kedudukan dalam lingkungan sosialnya. Mereka akan dinilai sebagai orang tua yang sukses karena telah mendidik anak perempuannya dengan baik, sehingga mampu bermenantukan orang yang tepat dari kalangan yang tepat pula. Hal ini sejalan dengan Wilson (Wafiroh, 2010: 31) bahwa perjodohan dalam pernikahan bisa menjadi tujuan ekonomi karena harta benda (property) yang dimiliki keluarga akan terjaga dan terkontrol.

Kutipan tersebut menunjukan ikonitas yang merendahkan kedudukan perempuan. Bukan dari segi harga diri ataupun kehormatan, melainkan dari segi pendapat. Artinya kaum perempuan tidak dibebaskan untuk berpendapat. Mereka harus tunduk pada perintah orang tua. Tindakan perjodohan sebagaimana yang terjadi dalam kutipan tersebut menjadi bukti kesewenang-wenangan orang tua terhadap anak perempuan. Anak perempuan digunakan sebagai wadah untuk menukar masa depan dengan kekuasaan dan kehormatan keluarga.

Ikonitas perempuan juga tercermin dalam sampul novel grafis Embroideries karya Marjane Satrapi. Secara ikonik imagi, sampul novel grafis Embroideries terlihat cukup artistik. Terdapat gambar seorang perempuan yang berparas cantik sedang tersenyum. Perempuan tersebut dikelilingi oleh bingkai, kemudian bingkai tersebut memiliki ukiran seperti bordir. Pada keempat sudut bingkai yang dibordir juga terdapat gambar benda tajam menyerupai tombak. Gambar sampul tersebut menjadi tanda bahwa perempuan 
adalah perhiasan yang berharga dan karenanya mesti dijaga kehormatannya.

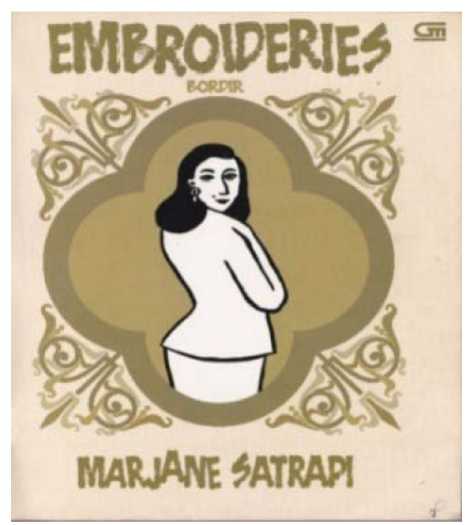

Sampul Novel Grafis Embroideries

Sumber: Novel Grafis Embroideries 2006

Gambar sampul novel grafis Embroideries sengaja ditempatkan pada data yang terakhir karena sampul tersebut merupakan data yang dapat mewakili keseluruhan tanda yang mengandung ikonitas perempuan. Secara keseluruhan cerita, pengarang novel grafis Embroideries lebih cenderung menonjolkan sosok perempuan ditinjau dari sudut pandang Iran, karenanya sampul novel tersebut dirancang sedemikian rupa sehingga mampu mewakili gambaran sosok ideal perempuan dalam pandangan masyarakat Iran. Hubungan antara perempuan yang terkurung di dalam bingkai indah dan mewah tetapi tajam seperti tombak pada setiap sisinya dimaknai sebagai perhiasan yang berharga dan setiap perhiasan tentu akan dijaga dengan sebaik-baiknya.

Bagian sampul novel ini telah menggambarkan tentang bangsa Timur yang diwakili oleh negara Iran sebagai latar cerita pada novel grafis ini, sangat menjunjung tinggi kehormatan perempuan. Sampul novel grafis tersebut menjadi ikonitas mengenai sosok perempuan sempurna. Perempuan selain memiliki paras yang cantik sesuai kodrat yang dia miliki, murah senyum dan ramah, dia juga harus bisa menjaga dirinya dari segala bentuk kejahatan yang dapat merusak citranya di lingkungan keluarga maupun masyarakat luas. Bingkai yang indah, terlihat mewah, serta terdapat tombak dikeempat sisinya yang mengelilingi perempuan dalam sampul novel grafis tersebut mengindikasikan penjagaan terhadap seorang perempuan.

Ilustrasi sampul novel grafis Embroideries tersebut adalah ikonitas yang mengangkat kedudukan perempuan di mata masyarakat Iran. Perempuan dijaga sedemikian ketat karena hakikatnya perempuan adalah sosok istimewa. Perempuan dianggap seperti perhiasan yang paling berharga sehingga menempatkannya pada tempat yang indah pula, yaitu bingkai yang dikelilingi tombak dan terlihat mewah. Perempuan membawa sesuatu yang istimewa dan tidak sembarang orang dapat mengambilnya dengan mudah.

\section{Ikon Diagramatis Perempuan dalam Novel Grafis Embroideries karya Marjane Satrapi}

Pola pikir masyarakat Iran menganggap bahwa kemurnian atau kesucian seorang perempuan diukur berdasarkan status "perawan" yang disandangnya. Keperawanan tidak sekadar tolak ukur bagi kehormatannya sendiri melainkan juga kehormatan keluarganya. Setiap anak perempuan yang kehilangan keperawanannya akan berusaha untuk memulihkan kehormatan dengan berbagai cara. Hal ini dapat dilihat dalam kutipan berikut.

"Ini, ambillah pisau silet ini. Nanti pada malam pertama, rapatkan kedua pahamu erat-erat, lalu menangislah amat sangat keras, dan kalau sudah waktunya, gores kulitmu sedikit, sedikit saja! Kau akan berdarah sedikit. Dia akan bangga dengan kejantanannya, dan kehormatanmu tetap terjaga." (Embroideries, 2006:17)

Jika ditinjau secara ikonik diagramatis, kutipan teks tersebut menjelasakan serangkaian kegiatan yang tersusun dan 
harus dilakukan oleh tokoh Nahid guna melindungi kehormatannya di hadapan suaminya. Tragedi silet sebagaimana dalam kutipan tersebut menjadi ikonitas kehidupan perempuan Iran yang kehilangan hymen. Keberadaan hymen menjadi bukti keseriusan perempuan dalam menjaga kesucian dan kehormatannya. Hymen juga menjadi saksi bahwa perempuan tersebut belum pernah melakukan hubungan seksual sebelum menikah sebagaimana telah menjadi hukum yang diyakini masyarakat Iran yang bersandar pada agama sebagai pedoman hidup.

Berdasarkan kutipan yang telah dipaparkan tersebut, dapat diketahui adanya hubungan antara keperawanan dan pola pikir masyarakat Iran, yaitu ketika status sebagai seorang perawan menjadi ukuran kehormatan dirinya dan keluarganya. Kutipan tersebut menunjukan ikonitas perempuan yang berusaha menjaga dan mempertahankan kehormatannya di hadapan suaminya, meski dengan cara menggores kulitnya sehingga berdarah agar disangka masih perawan.

Persoalan lain menyangkut kehidupan perempuan di dalam novel grafis Embroideries juga dimunculkan melalui kisah yang dialami oleh tokoh Shideh. Kehidupan tokoh Shideh menjadi ikonitas perempuan Iran yang terjerat dalam kehidupan sekuler seperti free sex (seks bebas). Akibat mengikuti saran dari perempuan pemilik ilmu sihir putih, tokoh Shideh melakukan sebuah perbuatan yang bertentangan dengan nilai moral yang berlaku dalam lingkungannya. Hal ini dapat dilihat dalam kutipan berikut.

"Ini! ambil kunci ini. Kau mesti menyeduh teh. Lalu ajak dia tidur. Begitu dia ejakulasi---hati-hati! Dia mesti keluar di dalammu--- masukkan kunci ini ke vaginamu. Hitung sampai 7. Lalu keluarkan kunci ini dan masukkan ke cangkir. Tuang tehnya, hitung sampai 7. Terakhir, ambil kuncinya, teh ini mesti diminum pujaan hatimu dalam waktu 77 detik setelah dia ejakulasi. Nah, ongkos kosultasinya 3.000 tuman." (Embroideries, 2006: 56)

Secara ikonik diagramatis kutipan tersebut menunjukan serangkaian proses yang harus dilakukan oleh tokoh Shideh sesuai dengan saran perempuan pemilik ilmu sihir putih. Pada kalimat kau mesti menyeduh teh. Lalu ajak dia tidur. Begitu dia ejakulasi---hati-hati! Dia mesti keluar di dalammu menunjukan adanya perbuatan seks bebas yang harus dilakukan oleh tokoh Shideh. Kultur Iran yang dibangun atas dasar agama sebagai pedoman hidup tidak membenarkan hal seperti ini terjadi. Seorang perempuan meskipun telah menjanda bukan berarti bisa bebas bercinta dengan siapa saja.

Kutipan tersebut adalah bentuk ikonitas yang merendahkan perempuan. Tokoh Shideh disarankan oleh perempuan pemilik ilmu sihir putih untuk tidur dengan kekasihnya. Hal ini membuktikan sebuah perbuatan seks bebas dan politik seksual perempuan dengan menggunakan ritual ilmu sihir sebagai wadahnya. Pelaksanaannya dapat dilakukan dengan beragam cara dan alasan-alasan yang mistis, yakni untuk membuat kekasih dari tokoh Shideh tidak berpaling kepada perempuan lain. Padahal secara logika, tidak ada jaminan bahwa kekasih tokoh Shideh akan tetap mencintai Shideh jika dia menyerahkan dirinya pada kekasihnya.

Ikon Metaforis Perempuan dalam Novel Grafis Embroideries

Perjodohan dijadikan sebagai motif untuk mengangkat derajat atau mempertahankan kedudukan kaum aristokrat di Iran. Perjodohan yang dialami oleh tokoh Bahar menunjukan ikonitas perempuan Iran yang sering menjadi alat untuk menukar kekuasaan. Tokoh Bahar dinikahkan dengan laki-laki dari kalangan kelas atas. Laki-laki yang dinilai ibunya sebagai seorang laki-laki yang baik dan tinggal di London selama puluhan tahun. Namun pada saat pernikahannya, laki-laki 
tersebut tidak datang untuk menghadiri acara pernikahannya sendiri. Tokoh Bahar hanya disandingkan dengan foto suaminya, sementara suaminya tetap tinggal di London. Hal ini dapat dilihat dalam ilustrasi berikut.

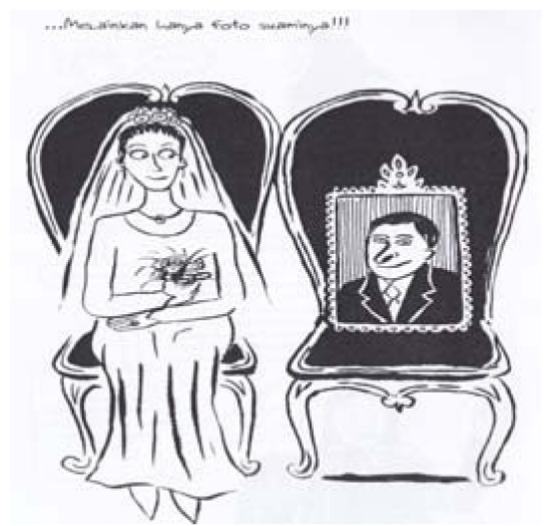

(Gambar sepasang pengantin) Sumber: Novel Grafis Embroideries, 2006: 92

Ilustrasi di atas menunjukan sepasang pengantin yang duduk di pelaminan. Namun, bukan mempelai laki-laki yang duduk mendampingi mempelai perempuannya melainkan hanya fotonya saja. Ilustrasi ini menandai adanya penghinaan pada pihak perempuan. Sepasang pengantin seharusnya duduk berdampingan dan bukan malah diwakilkan oleh sebuah foto. Tindakan ini menunjukan bagaimana seorang anak perempuan hanya dijadikan sebagai alat untuk menukar kekuasaan dan kehormatan. Hanya karena laki-laki tersebut adalah seorang multijutawan dari Inggris, bukan berarti dia bisa menikahi tokoh Bahar dengan cara seperti itu.

Secara ikonik metaforis, ilustrasi tersebut mengandung dua tanda simbolis, yaitu pengantin perempuan dan foto. Keduanya merupakan similaritas antara seorang perempuan dan sebuah foto yang dianggap merujuk pada objek yang mirip. Relasi yang terbangun antara pengantin perempuan dan foto yaitu keduanya sama-sama memiliki sifat tidak mampu berbuat apa-apa (tidak berdaya). Perempuan dalam ilustrasi tersebut menandai ikonitas perempuan Iran pada umumnya yang tidak mampu berbuat apa-apa, serta harus tunduk pada perintah orang tua. Demikian pula dengan foto yang merupakan benda mati, sebuah foto tentunya memang tidak mampu berbuat apa-apa. Foto menjadi tanda yang tepat untuk mendampingi tokoh Bahar sebagai ikonitas perempuan Iran dan menunjukan bahwa perempuan kebanyakan tidak mampu untuk menentukan jalan hidupnya sendiri.

Ilustrasi tersebut sekaligus menjadi ikonitas yang merendahkan perempuan. Perempuan disandingkan dengan sebuah foto, menunjukan bahwa perempuan hanyalah aset yang bisa dipajang. Bahkan kedudukan laki-laki dianggap superior, hanya dengan sebuah foto tetapi mampu menikahi seorang perempuan dari kalangan aristokrat. Dalam hal ini kedudukan perempuan ditempatkan pada posisi yang tidak berdaya, tertindas, serta tidak dapat menolak kekuasaan laki-laki. Kedudukan perempuan sebagai makhluk yang tidak berdaya dan tertindas menurut Naqiyah (2005: 53) sudah menyejarah berabadabad lamanya dikarenakan berbeda jenis kelamin. Oleh sebab itu, tokoh Bahar dalam ilustrasi tersebut menjadi ikonitas perempuan yang tidak berdaya, sekaligus dipandang sebagai sosok yang boleh dilecehkan. Tokoh Bahar dipandang sebagai bentuk ketertindasan dan kekalahan perempuan di hadapan laki-laki.

\section{SIMPULAN}

Berdasarkan hasil penelitian terhadap novel grafis Embroideries karya Marjane Satrapi yang telah dijabarkan sebelumnya, dapat disimpulkan bahwa ditinjau melalui perspektif tanda ikon, terdapat tiga belas data yang mengandung ikonitas perempuan Iran. Data yang mengandung ikonitas perempuan dalam novel grafis tersebut terdiri dari sepuluh ikon imagi, dua ikon diagramatis, dan satu ikon metaforis. Melalui ketiga jenis ikon tersebut, data yang mengandung ikonitas perempuan lebih didominasi 
oleh kutipan-kutipan yang merendahkan kaum perempuan. Ikonitas perempuan yang terungkap melalui ketiga jenis tanda tersebut merepresentasikan pola pikir masyarakat Iran terhadap perempuan, yakni keperawanan yang menjadi ukuran kehormatan perempuan dan keluarganya. Perempuan dianggap terhormat serta memiliki moralitas yang tinggi ketika dia berhasil menjaga kesuciannya. Pada kenyataannya, novel grafis ini mengungkapkan bahwa anak perempuan banyak menjadi korban kebudayaan, hingga membuat mereka mendobrak kultur yang kolot dan fanatis dengan terjun langsung ke dalam pergaulan bebas. Akibatnya, tidak sedikit perempuan yang kehilangan keperawanan sejak masih gadis. Usaha yang mereka lakukan untuk menutupi aibnya adalah dengan menjahit kembali selaput dara (hymenoplasty). Ada juga yang menggunakan silet untuk menggores kulit tangannya sendiri sehingga berdarah agar disangka masih perawan. Hal ini adalah usaha-usaha yang dilakukan perempuan untuk mempertahankan kehormatannya. Usaha menjaga kehormatan perempuan ini pun tak luput dari peran orang tua. Orang tua merasa perlu terlibat dalam kehidupan anak perempuannya, sehingga mereka menjadikan praktik perjodohan sebagaimana yang diungkapkan dalam novel grafis ini sebagai usaha untuk menyelamatkan anak perempuan dari pergaulan bebas. Namun tanpa disadari orang tua bahwa perjodohan yang terjadi merupakan bentuk kesewenang-wenangan orang tua terhadap anak perempuannya. Perempuan menjadi objek yang tidak dapat menolak kekuasaan, sebagaimana tokoh Bahar yang dihadirkan pengarang sebagai salah satu figur yang menjadi ikonitas perempuan dalam kultur Iran. Tokoh Bahar dilihat sebagai bentuk ketertindasan dan kekalahan perempuan di hadapan laki-laki, sebab dia disandingkan hanya dengan sebuah foto. Demikian dapat diketahui bahwa setiap usaha untuk menjaga kaum perempuan dari perbuatan yang melanggar norma sosial, malah akan berakhir dengan mengorbankan kedudukan dan kebebasan kaum perempuan.

\section{UCAPAN TERIMA KASIH}

Artikel ini merupakan hasil penelitian kolaborasi bersama Mahasiswa Universitas Negeri Gorontalo, Jurusan Bahasa dan Sastra Indonesia, berjudul "Ikonitas Perempuan dalam Novel Grafis Embroideries Karya Marjane Satrapi“. Peneliti menyampaikan terima kasih kepada semua pihak yang telah mendukung dan memberikan kebijakan terlaksananya penelitian ini. Ucapan terima kasih peneliti sampaiakn terutama kepada Ketua Jurusan Bahasa dan Sastra Indonesia serta Dekan Fakultas Sastra dan Budaya UNG. Peneliti bertanggung jawab sepenuhnya secara ilmiah terhadap isi dan hasil penelitian ini.

\section{DAFTAR RUJUKAN}

Budiman, Kris. 2011. Semiotika Visual: Konsep, Isu, dan Problem Ikonitas. Yogyakarta: Jalasutra

Frey, Nancy dan Douglas Fisher. 2008. Teaching Visual Literacy: Using Comic Books, Graphic Novels, Anime, Cartoons, and More to Develop Comprehension and Thinking Skills. California: Corwin Press

Jamaluddin. 2013. Sekularisme: Ajaran dan Pengaruhnya dalam Dunia Pendidikan. Jurnal Muddarissuna Vol. 3. Banda Aceh: Prodi PAI FTK UIN Ar-Raniry Banda Aceh.

Muhith, M (ed.). 2003. Gender Voices: Telaah Kritis Relasi Bahasa-Gender. Pasuruan: Pedati

Naqiyah, Najlah. 2005. Otonomi Perempuan. Malang: Bayumedia Publishing

Noor, Redyanto. 2005. Pengantar Pengkajian Sastra. Semarang: Fasindo

Satrapi, Marjane. 2006. Embroideries. Jakarta: PT Gramedia Pustaka Utama 
Sopariyanti, Pera. 2008. Menilai Kawin

Paksa: Perspektif Figh dan Perlindungan Anak. Jakarta Selatan: Rahima
Tinarbuko, Sumbo. 2013. Semiotika Komunikasi Visual. Yogyakarta: Jalasutra Wafiroh, Nihayatul. 2010. Kemiskinan dan Perjodohan. Jakarta Selatan: Rahima 